\title{
Jolanta Monytz
}

Uniwersytet Warszawski

j.morytz@uw.pl

\section{STRATEGIE KOMUNIKACYJNE W OBLICZU TRUDNOŚCI JĘZYKOWYCH}

\section{Communication strategies in the face of language difficulties}

Foreign language classes at university should enhance not only knowledge of foreign languages but with the use of different methods, should also develop skills of communication strategies, which are very important to compensate for deficits in communication. These strategies are indispensable for language learners irrespective of their level of proficiency. The objective of the study described in the present paper is to explore the communication strategies used by Polish students at different levels of knowledge of Italian. Data was collected by two types of questionnaires, one including two open-ended questions. The other was based on a Likert-scale method which examined the frequency of usage of avoidance strategies, verbal and non verbal strategies, as well as the strategy of transfer. Emphasis was placed on the relationship between the use of types of communication strategies and students' level of proficiency. In the final part the author recommends types of lexical exercises which should be practised during classes to help students to develop their communicative skills.

Keywords: communicative strategies, avoidance strategies, verbal strategies, non verbal strategies, strategy of transfer

Słowa kluczowe: strategie komunikacyjne, strategie uniku, strategie językowe, strategie pozajęzykowe, strategia transferu 


\section{Wstęp}

W dobie globalizacji, dzięki możliwości podróżowania, coraz częstsze stają się kontakty z cudzoziemcami na polu towarzyskim i zawodowym. Osoby wywodzące się z różnych obszarów językowych muszą znaleźć odpowiedni sposób porozumiewania się. W przypadku trudności w doborze odpowiednich form językowych, rozmówcy stosują różnorodne środki werbalne i pozawerbalne, umożliwiające im nawiązanie kontaktu i wymianę informacji.

W artykule podjęto próbę zdefiniowania pojęcia strategii komunikacyjnej rozumianej w dwojaki sposób - w komunikacji między rodzimymi użytkownikami języka oraz w obliczu trudności językowych napotykanych podczas komunikowania się w języku obcym.

Po omówieniu teorii przedstawione zostaną wyniki badania, którego celem było poznanie rodzajów strategii stosowanych przez osoby uczące się języków obcych. W artykule zostanie przeprowadzona analiza współzależności między poziomem znajomości języka włoskiego a rodzajem stosowanych strategii.

Wyniki badania pozwolą na wysunięcie wniosków na temat tego, jakie umiejętności powinny być ćwiczone podczas lektoratu w celu usprawnienia komunikacji w języku obcym oraz jaki rodzaj ćwiczeń jest najbardziej odpowiedni.

\section{Warunki sprawnej komunikacji}

Jakobson ([1966] 1989: 68) cytuje Edwarda Sapira: „M owa jest procesem komunikacyjnym par excellence w każdym znanym społeczeństwie". Dalej pisze, że podczas aktu komunikacji należy rozróżnić rozmaite relacje zachodzące między jej uczestnikami. Rozmówcy naprzemiennie podejmują rolę osoby kodującej i deszyfrującej. Komunikacja przebiega sprawnie, kiedy rozmówcy posługują się wspólnym kodem i starają się dostosować styl wypowiedzi do kontekstu sytuacyjnego oraz do możliwości językowych i intelektualnych swojego rozmówcy, jego nastawienia i znajomości tematu (Corder 1982: 103). Mówiąc o języku, należy podkreślić, że spełnia on różne funkcje: referencyjną, emotywną, konatywną, fatyczną, poetycką i metajęzykową (Jakobson 1989: 68). 0 funkcji referencyjnej mówimy, kiedy odnosi się ona do kontekstu rozmowy, wspólnego dla nadawcy i odbiorcy; o funkcji emotywnej, kiedy komunikat skupiony jest na nadawcy; o funkcji konatywnej, kiedy nadawca kieruję swą uwagę na odbiorcę i ma na niego wpływ; o fatycznej, kiedy komunikowana treść ma mniejszą wagę niż fakt nawiązania i podtrzymania kontaktu; o funkcji poetyckiej, kiedy komunikat skupiony jest na samym sobie; natomiast o funkcji metajęzykowej, kiedy język skupiony jest na kodzie. Naruszenie jednego z 
czynników może wpłynąć na płynność przebiegu rozmowy, jej załamanie lub mylne zrozumienie intencji wypowiadającego się.

Pawlak (2014: 12) odwołuje się do modelu zaproponowanego przez Canale'a i Swain (1980), według których kompetencja komunikacyjna opiera się na czterech aspektach dotyczących wiedzy i umiejętności jej zastosowania. Pierwszy z nich to kompetencja gramatyczna, czyli znajomość systemu językowego: fonologii, leksyki, składni. Drugi odnosi się do kompetencji socjolingwistycznej, umiejętności tworzenia aktów wypowiedzi stosownych do kontekstu sytuacyjnego i specyfiki kulturowej. Trzeci dotyczy kompetencji dyskursywnej, tj. umiejętności tworzenia logicznych i spójnych wypowiedzi w mowie i piśmie. Czwarty to kompetencja strategiczna, czyli umiejętność zastosowania sposobów wpływających na jakość komunikacji lub kompensację w przypadku braku kompetencji lingwistycznych.

\section{Rodzaje strategii komunikacyjnych}

Zastosowanie różnorodnych strategii komunikacyjnych pozwala zachować większą kontrolę nad toczącą się konwersacją z punktu widzenia konstruowania własnej wypowiedzi, ale też podejścia do rozmówcy. Jak twierdzi Wilczyńska (1999: 63), funkcja komunikacyjna nie może być opisywana jedynie poprzez pryzmat przekazu konkretnych informacji. Nakładają się na nią funkcja „towarzyska” i „autoekspresyjna”. Konwersacja służy nie tylko przekazaniu treści, istotne jest także podtrzymanie i zacieśnienie relacji międzyludzkich i wyrażenie siebie w akcie mowy.

Rodzimi użytkownicy języka stosują zazwyczaj intuicyjnie, bez świadomości metajęzykowej, odpowiednie strategie komunikacyjne. Dla rozmówców posługujących się językiem rodzimym (JR) jest to proces naturalny. Strategie wpływające na jakość konwersacji proponuję określić mianem „strategie optymalizacyjne". Strategie tego typu mogą być zastosowane w sytuacjach, kiedy uczestnik rozmowy pragnie okazać swoje zainteresowanie i zachęca rozmówcę słowami: doprawdy?; hm, ciekawe. Kiedy chce się upewnić, że dobrze rozumie intencje rozmówcy lub podąża za wątkiem jego wypowiedzi, używa w sposób naturalny wyrażeń typu: co właściwie rozumiesz przez...?; to znaczy, że...?; podsumowujqc... Kiedy ma odmienny pogląd, posłuży się wyrażeniami: no, nie wiem...; spójrzmy na to z innej strony.

Podczas komunikacji z użyciem języka obcego (J) jest inaczej. Z psychologicznego punktu widzenia, wypowiedź w JO jest o wiele trudniejsza niż w JR: trzeba włożyć w nią większy wysiłek intelektualny, aby nadać przekazywanej treści odpowiednią formę. Angażując się w działania komunikacyjne, uczący się napotyka różne trudności wynikające z niepełnej kompetencji. Przyswajając J0, student jest zmuszony komunikować się przy poważnym niedoborze środków 
pod względem leksykalnym, umiejętności zastosowania struktur gramatycznych i składniowych, trudności w wymowie. Deficyty w różnych obszarach mogą utrudniać, zniekształcać albo wręcz uniemożliwiać komunikację. Piotrowski (2016: 28) wskazuje, że uczący się ma wtedy do wyboru trzy podstawowe rozwiązania: (i) wycofać się z realizacji zamierzonego celu, przerywając wypowiedź lub zmieniając temat, (ii) próbować przezwyciężyć trudność samodzielnie, (iii) poprosić o pomoc w języku rodzimym lub docelowym.

W literaturze światowej istnieje wiele podejść do tematu strategii komunikacyjnych, w ramach których opracowano różne taksonomie. Corder (1982: 104-105) rozróżnia dwie postawy wobec wyzwań językowych: strategie dostosowaw cze wiążące się z unikaniem ryzyka (ang. risk avoidance) poprzez zaniechanie rozmowy lub porzucenie tematu. Strategia uniku to takze wprowadzenie zmian w stosunku do pierwotnych zamierzeń, zredukowanie tematu, zastosowanie pojęć uogólniających. Strategie te polegają na częściowym uniku, albowiem temat zostaje jednak podjęty. Strategie nastawione na poszerzanie wiedzy (ang. risk running) to takie, z którymi łączy się wprawdzie ryzyko narażenia się na błędy, lecz z drugiej strony przyczyniają się one do rozwoju umiejętności. Wyróżniamy tu: zapożyczenia z języka ojczystego, parafrazę, gesty i mimikę, proszenie o pomoc rozmówcę, zapożyczenia z innego języka obcego.

Tarone (1977) (za Pawlak 2014: 16-17) proponuje klasyfikację strategii: unik (unikanie tematu, zaniechanie przekazu); parafraza (omówienie, przybliżenie, tworzenie słów); transfer (dosłowne tłumaczenie, przełączenie kodu); prośba o pomoc (np. nauczyciela); mimika i gesty.

Jak wskazuje Corder (1982: 104-105), wielu badaczy uważa, że strategie komunikacyjne i strategie uczenia się są prawie synonimami. Opinię tę rozważa on w kontekście hipotezy, która zakłada istnienie interjęzyka w procesie akwizycji j O przedstawionej przez Selinkera (1972). Stosowane techniki mogą przynależeć do obydwu strategii, np. prośba o pomoc może być wypowiedziana w obliczu niezrozumienia przekazu zarówno przez osobę porozumiewającą się w JO, jak i rodzimego użytkownika języka.

W warunkach naturalnych tzw. komunikacja przeżycia nastawiona jest na osiągnięcie celu komunikacyjnego wszelkimi środkami. Aby uzyskać potrzebne informacje czy załatwić niezbędne formalności, w przypadku niewystarczających umiejętności językowych trzeba rozwijać cały szereg strategii, które pomogą w osiągnięciu celu. W warunkach instytucjonalnych, a do takich należy nauka języka obcego w szkole czy na uniwersytecie, sytuacja wygląda inaczej. Piotrowski (2013: 122), powołując się na badania Porquier (1979), zwraca uwagę na fakt, że pojawiają się tzw. strategie szkolne, które nie są nastawione na komunikację, ale na wypełnienie polecenia i rozwiązanie określonego zadania minimalnym nakładem sił. 
M ożna by przypuszczać, że osoby uczestniczące w lektoratach, znające inne języki obce i podróżujące po świecie, posiadające pewne doświadczenie w komunikowaniu się, rozwinęły już w sposób naturalny odpowiednie strategie ułatwiające interakcje personalne i społeczne. Studenci polskich uczelni uczęszczają na lektoraty składające się w głównej mierze z Polaków. Wszyscy uczestnicy należą do tego samego kręgu językowego i kulturowego. Kiedy okazuje się, że w trakcie ćwiczeń komunikacyjnych nie znają odpowiedniego słowa włoskiego, stosują technikę transformacji językowej - zastępują nieznane słowo włoskie odpowiednikiem polskim.

\section{Projekt badawczy}

Do refleksji skłoniły mnie obserwacje poczynione podczas prowadzenia lektoratów języka włoskiego. Kiedy studenci w trakcie ćwiczeń mających na celu rozwijanie sprawności komunikacyjnych napotykają deficyty językowe, zbyt szybko przechodzą na język polski. Sytuacje szkolne, dalekie od komunikacji przeżycia, nie rozwijają strategii, których studenci użyliby w naturalnych warunkach.

W niniejszym artykule podstawę do omówienia kwestii strategii komunikacyjnej stanowią wyniki badania, które zostało przeprowadzone podczas lektoratów języka włoskiego. Jednym z celów badania było zweryfikowanie, czy studenci mają świadomość stosowania strategii komunikacyjnych. Drugim celem było zaobserwowanie, jakie strategie są najczęściej stosowane podczas prowadzenia konwersacji w J0. Trzecia kwestia poddana analizie służyła rozważeniu, czy repertuar stosowanych strategii zmienia się wraz ze wzrostem poziomu znajomości języka.

\subsection{Uczestnicy badania}

Zaprezentowane badanie zostało przeprowadzone wśród studentów studiujących na różnych kierunkach niefilologicznych, na studiach licencjackich. Lektoraty, w których uczestniczą studenci, odbywają się dwa razy w tygodniu i trwają po dwie godziny lekcyjne. Badania przeprowadzono na początku semestru letniego, po zakończeniu sześćdziesięciogodzinnego szkolenia w semestrze zimowym. Nie odnotowano, jak długo i w jakich okolicznościach studenci studiowali język przed rozpoczęciem lektoratu na uniwersytecie. Poziom zaawansowania językowego grup określono według skali ESOKJ. W badaniu uczestniczyło 78 studentów studiujących na różnych poziomach: A2 (27 studentów), B1 (25 studentów) i B2 (26 studentów). Badanie przeprowadzono w grupach nauczanych przez różnych lektorów. 


\subsection{Opis badania}

Badanie przeprowadzono za pomocą dwóch kwestionariuszy, jednego bazującego na metodzie jakościowej, drugiego - ilościowej. Pierwszy kwestionariusz zawiera dwa pytania otwarte sformułowane w języku polskim, tak aby studenci mieli możliwość wypowiedzenia się na ten temat bez ograniczeń ze strony językowej. Pytania otwarte poprzedzają drugą część kwestionariusza, zawierającą pytania zamknięte. Taka kolejność technik badawczych umożliwia badanym udzielenie samodzielnej odpowiedzi, bez zewnętrznych sugestii.

Pytania z pierwszej części badania są następujące:

1. "Jak postępujesz podczas rozmowy z obcokrajowcem, kiedy nie potrafisz wypowiedzieć w języku obcym tego, co chciałbyś wyrazić?"

2. "Jak postępujesz podczas rozmowy z obcokrajowcem, kiedy nie rozumiesz jego wypowiedzi?"

Druga część badania, zawierająca pytania zamknięte, składa się z trzech głównych punktów. Pierwszy sprawdza, jaki rodzaj strategii jest najczęściej podejmowany podczas trudności komunikacyjnych: strategia uniku, transferu z innego języka, zastosowanie środków pozajęzykowych czy językowych. Drugi dotyczy pytania o strategie językowe deklarowane przez badanych w momencie, gdy napotykają trudności w wypowiadaniu się w J0. Trzeci punkt ma na celu sprawdzenie, jakie strategie postępowania podejmują studenci w obliczu trudności receptywnych. Uczestnicy badania wskazywali odpowiedzi na pięciostopniowej skali Likerta. Odpowiedzi nr 1 i nr 2 były pozytywne o różnym stopniu natężenia, odpowiedź nr 3 to odpowiedź neutralna, odpowiedzi nr $4 \mathrm{i}$ nr 5 wskazywały na negatywne nastawienie do zaznaczonej kwestii.

\subsection{Omówienie pytań otwartych}

Studenci odpowiadali własnymi słowami na pytanie „Jak postępujesz podczas rozmowy z obcokrajowcem, kiedy nie potrafisz wypowiedzieć w języku obcym tego, co chciałbyś wyrazić?". Wśród samodzielnych odpowiedzi można wyróznić 20 rodzajów stosowanych strategii.

Stosując taksonomię Tarone, podane odpowiedzi można sklasyfikować następująco: punkty 1-9 to strategie podjęcia wysiłku na poziomie werbalnym, 10-11 to transfer z innego języka. Punkty 12-17 określam jako prośbę 0 pomoc. Punkty 18-20 to wyrażanie informacji za pomocą środków pozawerbalnych. W przypadku napotkania trudności w sformułowaniu wypowiedzi, studenci nie wspominają o odmowie współpracy, chociaż nie można stwierdzić z pewnością, że nie stosują strategii uniku w sytuacjach rzeczywistych. 
Odpowiedź ujęta w punkcie 12, czyli „korzystanie z translatora w telefonie", może być analizowana jako strategia na poziomie werbalnym. Jednak można ją ująć także jako strategię określaną „prośba o pomoc”, albowiem studenci nie czerpią z zasobów własnych umiejętności lingwistycznych, tylko odwołują się do pomocy czynników zewnętrznych.

\begin{tabular}{|c|c|c|c|c|c|}
\hline & Zastosowana strategia & $\begin{array}{c}\text { A2 } \\
(27 \text { odp.) } \\
\end{array}$ & $\begin{array}{c}\text { B1 } \\
\text { (25 odp.) }\end{array}$ & $\begin{array}{c}\text { B2 } \\
\text { (26 odp.) }\end{array}$ & \begin{tabular}{|c|} 
Razem \\
$(78$ odp.)
\end{tabular} \\
\hline 1. & Prostsze słowa & $19 \%$ & $28 \%$ & $42 \%$ & $29 \%$ \\
\hline 2. & Synonimy & & & $19 \%$ & $6 \%$ \\
\hline 3. & Ogólniki & $4 \%$ & & & $1 \%$ \\
\hline 4. & Metafora & & & $4 \%$ & $1 \%$ \\
\hline 5. & Skojarzenia & $7 \%$ & & $15 \%$ & $8 \%$ \\
\hline 6. & Opisowo & $4 \%$ & & $15 \%$ & $6 \%$ \\
\hline 7. & Przykłady & $4 \%$ & & $15 \%$ & $6 \%$ \\
\hline 8. & Uproszczenie wypowiedzi & & $4 \%$ & $8 \%$ & $4 \%$ \\
\hline 9. & Podanie kontekstu & & $4 \%$ & $15 \%$ & $6 \%$ \\
\hline 10. & Stowa o brzmieniu międzynarodowym & & $4 \%$ & & $1 \%$ \\
\hline 11. & Inny język/angielski & $52 \%$ & $44 \%$ & $42 \%$ & $46 \%$ \\
\hline 12. & Stownik/translator w telefonie & $37 \%$ & $40 \%$ & $15 \%$ & $31 \%$ \\
\hline 13. & Zakomunikowanie trudności w wypowiedzi & & $8 \%$ & $4 \%$ & $4 \%$ \\
\hline 14. & Prośba o pomoc rozmówcę & & $8 \%$ & $4 \%$ & $4 \%$ \\
\hline 15. & Wyjaśnienie, gdzie leży trudność w komunikacji & & & $4 \%$ & $1 \%$ \\
\hline 16. & Denerwuję się/informuję o tym & & & $12 \%$ & $4 \%$ \\
\hline 17. & Prośba o pomoc inną osobę & & $8 \%$ & $12 \%$ & $6 \%$ \\
\hline 18. & Gesty & $81 \%$ & $72 \%$ & $50 \%$ & $68 \%$ \\
\hline 19. & Napisanie/narysowanie & $7 \%$ & $12 \%$ & $8 \%$ & $9 \%$ \\
\hline 20. & Wskazanie na dany przedmiot & $4 \%$ & $8 \%$ & $4 \%$ & $5 \%$ \\
\hline
\end{tabular}

Tabela 1: „Jak postępujesz podczas rozmowy z obcokrajowcem, kiedy nie potrafisz wypowiedzieć w języku obcym tego, co chciałbyś wyrazić?".

Na poziomie strategii komunikacyjnych, stosowanych przy tworzeniu wypowiedzi własnej, studenci najczęściej deklarują stosowanie gestów (68\% wskazań ogólnych). Warto zaznaczyć, że wraz ze wzrostem znajomości języka procent wskazań spada (A2 - 81\%, B1 - 72\%, B2 - 50\%). Kolejną powszechnie deklarowaną strategią jest używanie innego języka obcego, często wskazywano wprost, że jest to język angielski (46\% wskazań ogólnych, A2 -51\%, B1 - 44\%, B2 - 42\%). Analizując użycie translatora (31\%), dostrzec można dużą różnicę w rozbiciu na poszczególne poziomy (A2 - 37\%, B1 - 40\%, B2 - 15\%). Następnie wskazano na użycie prostszych słów w tworzeniu wypowiedzi - wynik ogólny 29\% (A2 - 19\%, B1 - 28\%, B2 - 42\%).

Rozważając najczęściej używane strategie na poziomie A2, zauważamy, że powszechnie deklarowane jest wspomaganie się gestami (81\%), korzystanie z 
translatora (37\%), transfer z innego języka (52\%). Na poziomie B1 najchętniej wskazywaną strategią są także gesty (72\%), następnie użycie języka angielskiego (44\%) i korzystanie z translatora (40\%). Na poziomie B2 sytuacja przedstawia się inaczej: gesty (50\%), transfer z innego języka (42\%), używanie prostszych słów (42\%), podanie synonimów (19\%). Korzystanie z translatora podaje tylko 15\% badanych.

Studenci, odpowiadając na pytanie "J ak postępujesz podczas rozmowy z obcokrajowcem, kiedy nie rozumiesz jego wypowiedzi?", podali odpowiedzi, które zostały przeze mnie uogólnione do 17 typów strategii.

\begin{tabular}{|c|c|c|c|c|c|}
\hline & Zastosowana strategia & $\begin{array}{c}\text { A2 } \\
(27 \text { odp.) } \\
\end{array}$ & $\begin{array}{c}\text { B1 } \\
(25 \text { odp.) }\end{array}$ & $\begin{array}{c}\text { B2 } \\
(26 \text { odp.) }\end{array}$ & $\begin{array}{c}\text { Razem } \\
\text { (78 odp.) }\end{array}$ \\
\hline 1. & Prośba o powtórzenie & $48 \%$ & $48 \%$ & $73 \%$ & $56 \%$ \\
\hline 2. & Wolniej i wyraźniej & $26 \%$ & $12 \%$ & $\mathbf{2 7 \%}$ & $22 \%$ \\
\hline 3. & Inne/prostsze słowa & $41 \%$ & $28 \%$ & $58 \%$ & $42 \%$ \\
\hline 4. & Przykład/opis/wytłumaczenie & $7 \%$ & $8 \%$ & $19 \%$ & $12 \%$ \\
\hline 5. & Wskazanie nieznanego słowa & & $4 \%$ & $12 \%$ & $5 \%$ \\
\hline 6. & Wydedukowanie niezrozumiałego fragmentu z kontekstu & $7 \%$ & $4 \%$ & $4 \%$ & $5 \%$ \\
\hline 7. & Parafraza w celu upewnienia się & & & $8 \%$ & $3 \%$ \\
\hline 8. & Inny język/angielski & $30 \%$ & $24 \%$ & $23 \%$ & $26 \%$ \\
\hline 9. & Intuicja/skojarzenie z innymi językami & & $4 \%$ & & $1 \%$ \\
\hline 10. & Sygnalizowanie niezrozumienia, poproszenie rozmówcy o współpracę & & $20 \%$ & $27 \%$ & $15 \%$ \\
\hline 11. & Poproszenie innej osoby o pomoc & $4 \%$ & $8 \%$ & $12 \%$ & $8 \%$ \\
\hline 12. & Słownik/translator w telefonie & $19 \%$ & $20 \%$ & $4 \%$ & $14 \%$ \\
\hline 13. & Napisanie/rysowanie & $4 \%$ & $4 \%$ & $4 \%$ & $4 \%$ \\
\hline 14. & Gesty & $33 \%$ & $40 \%$ & $19 \%$ & $31 \%$ \\
\hline 15. & Udawanie zrozumienia & $4 \%$ & & $4 \%$ & $3 \%$ \\
\hline 16. & Zmiana tematu & & & $4 \%$ & $1 \%$ \\
\hline 17. & Odmowa współpracy & $7 \%$ & $16 \%$ & & $8 \%$ \\
\hline
\end{tabular}

Tabela 2: „Jak postępujesz podczas rozmowy z obcokrajowcem, kiedy nie rozumiesz jego wypowiedzi?".

Odwołując się do taksonomii Tarone, należy przyjąć, że wskazania ujęte w punktach 1-7 wpisują się w strategie podjęcia wysiłku na poziomie językowym. Wskazania 8-9 zaklasyfikowałam jako transfer. Punkty 10-12 należy sklasyfikować, według taksonomii Tarone, jako prośbę o pomoc. Punkty 13-14 rysowanie i gesty - to stosowanie środ ków pozajęzykowych. Natomiast punkty 15-17 to odmowa współpracy, czyli unik.

Najczęstszymi reakcjami studentów podczas niezrozumienia wypowiedzi interlokuto ra są: prośba o powtórzenie ( $56 \%$ wszystkich wskazań) i prośba o wyjaśnienie prostszymi słowami (42\%). Powszechne jest także wskazanie na użycie gestów (31\%). Kiedy te techniki zawodzą, studenci zaznaczają, że przechodzą na inny język (26\%) - w odpowiedziach wprost wskazywano na język angielski.

Na poziomie A2 najczęściej podawano prośbę o powtórzenie (48\%) lub skonstruowanie wypowiedzi w prostszy sposób (41\%), z dużą częstotliwością 
deklarowano użycie gestów (33\%) lub komunikację w innym języku (30\%). Na poziomie B1 powszechnie wskazywaną strategią była prośba o powtórzenie (48\%), stosowanie gestów (40\%), prośba o wytłumaczenie prostszymi słowami (28\%) lub rozmowa po angielsku (24\%). Na poziomie B2 studenci częściej deklarują próbę podjęcia wysiłku w celu zrozumienia wypowiedzi w J0. 73\% studentów podało jako najczęściej stosowane strategie: prośbę o powtórzenie, użycie innych, prostszych słów (58\%), mówienie wolniej i wyraźniej (27\%) oraz sygnalizowanie wprost rozmówcy niezrozumienia i prośbę o współpracę (27\%). Tylko 19\% studentów wspomniało o strategii stosowania gestów.

Analiza danych liczbowych pozwala wyciągnąć wnioski, że osoby z lepszą znajomością języka chętniej sygnalizują niezrozumienie wypowiedzi i są otwarte na współpracę ze swoim interlokutorem. Na poziomie B1 - 20\% udzieliło takiej odpowiedzi, na poziomie B2 - 27\%. Na poziomie A2 nikt nie wspomniał o takiej możliwości. Studenci lepiej znający język rzadziej korzystają z gotowych podpowiedzi, czyli z translatora (tylko 4\% wskazań na B2). Warto zaznaczyć, że studenci na wyższym poziomie zaznaczali, że sprawdzają słowo, którego nie mogą zrozumieć, natomiast na niższych poziomach wspominano o tłumaczeniu zdań w translatorze.

W dzisiejszych czasach studenci często wskazują na możliwość korzystania ze słowników elektronicznych w telefonach. Dawniej zpowodów technologicznych nie istniała taka możliwość. Warte zaznaczenia jest to, że taksonomie przedstawione przez Tarone i Cordera nie wspominają o możliwości korzystania ze słowniczków kieszonkowych. W warunkach konwersacji było to uciążliwe, ale przecież możliwe. Powyższe taksonomie nie uwzględniają możliwości rysowania, co sugerują niektóre odpowiedzi ankietowanych (3 odpowiedzi). Badania oceniane przez tych badaczy były ponadto prowadzone na użytkownikach języka angielskiego jako JO. Obecnie angielski stał się lingua franca i służy do porozumiewania się między członkami różnych narodowości, co znalazło swoje odzwierciedlenie we wskazaniach.

\subsection{Omówienie pytań zamkniętych}

W przedstawionych poniżej tabelach wskazano najczęściej udzielane odpowiedzi na poszczególne pytania dla danego poziomu. Tabela 3. analizuje rodzaj preferowanych strategii w momencie wystąpienia trudności komunikacyjnych podczas wypowiadania się w JO.

Analizując pierwsze pytanie, dotyczące strategii unikania podjęcia tematu, widzimy, że podejście uzależnione jest od poziomu znajomości języka włoskiego. 48\% studentów na poziomie A2 wskazało, że unika podjęcia tematu, 32\% odpowiedzi na poziomie B1 sugeruje niezdecydowanie, natomiast 31\% studentów na poziomie B2 deklaruje, że nie stosuje strategii uniku. Stosowanie strategii transformacji z innego języka obcego, wspominane tak chętnie w pytaniach 
otwartych przez studentów z niższą i średnią znajomością języka, potwierdza się także w pytaniach zamkniętych (A2 - 59\%, B1 - 48\%). Studenci na poziomie B2 nie deklarowali tego sposobu komunikowania się w odpowiedziach otwartych, ale w drugiej części badania potwierdzili powszechne jej stosowanie w przypadku trudności komunikacyjnych (42\% - raczej tak i 42\% - tak). Również stosowanie środków pozajęzykowych - mimika i gesty - deklarowane jest powszechnie na wszystkich poziomach (A2 - 52\%, B1 - 56\%, B2 - 42\%).

\begin{tabular}{|l|c|c|c|}
\hline & $\begin{array}{c}\text { A2 } \\
\text { (27 odp.) }\end{array}$ & $\begin{array}{c}\text { B1 } \\
\text { (25 odp.) }\end{array}$ & $\begin{array}{c}\text { B2 } \\
\text { (26 odp.) }\end{array}$ \\
\hline Nie podejmuję tematu & $48 \%$ (raczej tak) & $32 \%$ (trudno powiedzieć) & $31 \%$ (raczej nie) \\
\hline Porzucam/zmieniam temat & $44 \%$ (raczej nie) & $40 \%$ (raczej nie) & $38 \%$ (raczej nie) \\
\hline $\begin{array}{l}\text { Przechodzę na język, } \\
\text { który znam lepiej }\end{array}$ & $59 \%$ (tak) & $48 \%$ (raczej tak) & $42 \%$ (tak), 42\%(raczej tak) \\
\hline Stosuję mimikę, gesty & $52 \%$ (tak) & $56 \%$ (tak) & $42 \%$ (tak) \\
\hline Staram się wypowiedzieć & $44 \%$ (raczej tak) & $32 \%($ tak) & $58 \%$ (raczej tak) \\
\hline
\end{tabular}

Tabela 3: Jeżeli, rozmawiając w języku włoskim, napotykam trudności w wyrażeniu moich myśli i intencji to...

Odczytując zaznaczone odpowiedzi w tabeli 4, zauważamy, że w obliczu trudności pojawiających się w wypowiedzi ustnej studenci na wszystkich poziomach stosują podobne strategie.

Po analizie danych dotyczących strategii językowych można stwierdzić, że najwięcej odpowiedzi pozytywnych podano przy pytaniu dotyczącym deklaracji używania synonimów i antonimów (A2 - 67\% tak, B1 - 52\% tak, B2 - 54\% raczej tak). Zastosowanie opisu i definicji deklaruje znaczny procent studentów (A2 $67 \%$ tak, B1 - 52\% tak, B2 - 62\% tak). Nieco mniejszym uznaniem cieszą się strategie przykładów obrazujących oraz słowa wypełniacze. Studenci nie deklarują natomiast stosowania strategii tworzenia nowych słów, bazując na znajomości struktur morfologicznych. Nie stosują też strategii tłumaczenia wprost zJR.

\begin{tabular}{|l|c|c|c|}
\hline & $\begin{array}{c}\text { A2 } \\
\text { (27 odp.) }\end{array}$ & $\begin{array}{c}\text { B1 } \\
\text { (25 odp.) }\end{array}$ & $\begin{array}{c}\text { B2 } \\
\text { (26 odp.) }\end{array}$ \\
\hline Synonimy/antonimy & $67 \%$ (tak) & $52 \%$ (tak) & $54 \%$ (raczej tak) \\
\hline Opis/definicję & $67 \%$ (tak) & $52 \%$ (tak) & $62 \%$ (tak) \\
\hline Przykład uogólniający & $37 \%$ (raczej tak) & $44 \%$ (raczej tak) & $50 \%$ (tak) \\
\hline Przykład o węższym znaczeniu & $30 \%$ (tak) & $40 \%$ (raczej nie) & $31 \%$ (trudno powiedzieć) \\
\hline Przykłady obrazujące kategorię & $48 \%$ (tak) & $36 \%$ (tak) & $42 \%$ (raczej tak) \\
\hline Tłumaczę zjęzyka rodzimego & $33 \%$ (trudno powiedzieć) & $48 \%$ (raczej nie) & $46 \%$ (raczej nie) \\
\hline Tworzę nowe słowo & $41 \%$ (nie) & $36 \%$ (nie) & $46 \%$ (raczej nie) \\
\hline Używam wypełniacza & $37 \%$ (raczej tak) & $40 \%$ (tak) & $38 \%$ (raczej tak) \\
\hline
\end{tabular}

Tabela 4: Jeżeli napotykam trudności w wypowiedzi, to staram się używać... 
Przechodząc do tabeli 5, badającej zrozumienie wypowiedzi interlokutora, można stwierdzić, że odpowiedzi wskazane w pytaniach zamkniętych pokrywają się ze wskazaniami z pytań otwartych.

\begin{tabular}{|l|c|c|c|}
\hline & $\begin{array}{c}\text { A2 } \\
\text { (27 odp.) }\end{array}$ & $\begin{array}{c}\text { B1 } \\
\text { (25 odp.) }\end{array}$ & $\begin{array}{c}\text { B2 } \\
\text { (26 odp.) }\end{array}$ \\
\hline Proszę o powtórzenie & $81 \%$ (tak) & $76 \%$ (tak) & $65 \%$ (tak) \\
\hline Proszę o wyjaśnienie prostszymi słowami & $70 \%$ (tak) & $76 \%$ (tak) & $54 \%$ (tak) \\
\hline Parafrazuję Część wypowiedzi & $44 \%$ (raczej tak) & $36 \%$ (raczej tak) & $35 \%$ (raczej tak) \\
\hline Kieruję rozmowę na inne tory & $41 \%$ (raczej nie) & $40 \%$ (nie) & $42 \%$ (raczej nie) \\
\hline
\end{tabular}

Tabela 5: Jeżeli nie rozumiem mojego rozmówcy lub nie jestem pewny/a, czy dobrze zrozumiałem/am sens wypowiedzi i intencję rozmówcy, to...

Studenci, napotykając na trudności w zrozumieniu przekazu w J0, podają, że proszą o powtórzenie (A2 - 81\% tak, B1 - 76\% tak, B2 - 65\% tak) lub o wyjaśnienie prostszymi słowami (A2 - 70\% tak, B1 - 76\% tak, B2 - 54\% tak). Nie stosują raczej strategii uniku poprzez kierowanie rozmowy na inne tematy.

\section{Wnioski}

Badanie, którego wyniki zostały przedstawione w niniejszym artykule miało na celu pokazanie, jakie strategie komunikacyjne studenci deklarują się stosować w momentach braku kompetencji językowych podczas prowadzenia konwersacji w J0. Zaprezentowane badania skłaniają do wysnucia wniosku, że studenci w obliczu trudności komunikacyjnych w JO zbyt łatwo stosują środki pozajęzykowe w formie gestów, korzystają z translatora w telefonie i dokonują transferu z użyciem języka, którym lepiej władają.

W odpowiedzi na drugie pytanie, które postanowiono we wstępie artykułu, stwierdza się, że stosowanie wyżej wymienionych strategii kompensacyjnych jest praktykowane przez studentów na wszystkich poziomach znajomości języka włoskiego, chociaż oczywiście pojawiają się tu różnice - studenci na poziomie B2 w większym zakresie starają się stosować językowe strategie kompensacyjne i są znacznie bardziej otwarci na współpracę ze swoim rozmówcą.

W odpowiedzi na trzecie pytanie stwierdza się, że nauczyciele języków obcych powinni wyposażyć osoby uczące się JO w wiedzę metajęzykową, dotyczącą możliwości stosowania zróżnicowanych strategii komunikacyjnych. świadomość metajęzykowa uczących się jest bardzo istotnym czynnikiem. Studenci mogą bowiem zrozumieć naturalne procesy zachodzące podczas nauki J0, świadomie nimi kierować i stosować zaproponowane im strategie. W momentach deficytów językowych stosowanie strategii pozawerbalnych będzie skutkowało 
zbyt powolnym rozwojem umiejętności językowych, stałymi problemami komunikacyjnymi i nieumiejętnością stosowania technik strategii kompensacyjnych.

Strategie kompensacji to strategie umiejętnego zastosowaniu zastępczych środków językowych, polegające na zaradzaniu deficytom, zazwyczaj leksykalnym, poprzez zastąpienie nieznanych terminów synonimem, antonimem, hiperonimem, hiponimem, zastosowaniem omówienia itp. Warto zatem opracować i posiadać w warsztacie nauczycielskim ćwiczenia wspierające naukę słowotwórstwa, parafraz oraz techniki umiejętnego kierowania rozmową, wpływania na jej przebieg i jakość.

Nauczyciel, wprowadzając nowe pola semantyczne, powinien proponować studentom liczne ćwiczenia rozwijające umiejętności słowotwórcze. Doskonale służą temu celowi ćwiczenia wspierające myślenie kreatywne. Wpływają one na rozwój płynności i giętkości słownej, wyrażających się w umiejętności natychmiastowego przywoływania wielu różnorodnych słów.

Rozwijające są również ćwiczenia polegające na tworzeniu mind mapping, czyli mapy myśli, która ma służyć tworzeniu skojarzeń, grupowaniu wyrazów i kategoryzacji pojęć. Inną propozycją wspierającą ćwiczenia leksykalne jest klasowe pisanie rebusów i krzyżówek, dzięki którym rozwija się umiejętność tworzenia definicji i opisów.

Gra w kalambury słowne, mająca na celu tworzenie definicji oraz przywoływanie synonimów i skojarzeń słownych, również wpłynie na umiejętność szybkiego stosowania strategii komunikacyjnych w chwilach niedoborów leksykalnych. Wiele pomysłów na ćwiczenie kreatywności w glottodydaktyce zaprezentowano w artykule M orytz (2017). Zaleca się również używanie słowników monolingwalnych, zawierających definicje leksemów, które można opisywać poprzez synonimy.

Z czasem, po regularnym praktykowaniu tego rodzaju ćwiczeń leksykalnych, studenci zdobędą doświadczenie i będą w stanie wypracować własne strategie, nie tylko kompensacyjne, ale wręczoptymalizacyjne, wpływające na jakość konwersacji, i będą ich używać zgodne z własnym stylem wypowiedzi i sposobem uczenia się.

\section{BIBLIOGRAFIA}

Canale, M . i M. Swain. 1980. „Theoretical bases of communicative approaches to second language teaching and testing". Applied Linguistics 1: 1-47.

Corder, P. S. 1982. Error Analysis and Interlanguage. Oxford: Oxford University Press. Jakobson, R. 1989. W poszukiwaniu istoty języka. Wybór pism, t. 1. Warszawa: PIW. M orytz, J. 2017. „Nauczanie kreatywności podczas lektoratów języka ekonomicznego” (w druku).

Pawlak, M. 2014. „Strategie komunikacyjne w nauce języka obcego - próba integracji perspektyw". Konińskie Studia Językowe 2 (1): 11-33. 
Piotrowski, S. 2013. „0 strategiach w komunikacji egzolingwalnej w warunkach formalnych". Lingwistyka Stosowana 8: 117-131.

Piotrowski, S. 2016. „Strategie komunikacyjne, czyli jak uczący się radzą sobie z deficytami leksykalnymi w klasie języka obcego". Języki Obce w Szkole 1: 26-31.

Porquier, R. 1979. "Stratégies de communication en langue non-maternelle”. Travaux du Centre de Recherches Sémiologiques de Neuchâtel 33: 38-52.

Rada Europy. 2003. Europejski system opisu kształcenia językowego: uczenie się, nauczanie, ocenianie. Warszawa: Wydawnictwa CODN.

Selinker, L. 1972. „Interlanguage”. International Review of Applied Linguistics 10: 209-231.

Tarone, E. 1977. "Conscious communication strategies in interlanguage". (w) On TESOL'77: Teaching and Learning English as a second Language. (red. $\mathrm{H}$. Brown, C. Yorio i R. Crymes). Washington, DC: TESOL, str. 194-203.

Wilczyńska, W. 1999. Uczyć się czy być nauczanym? 0 autonomii w przyswajaniu języka obcego. Warszawa-Poznań: Wydawnictwo Naukowe PWN. 


\section{Aneks}

\section{Ankieta}

(1- tak, 2 - raczej tak, 3 - trudno powiedzieć, 4 - raczej nie, 5 - nie)

I. Jeżeli, rozmawiając $w$ języku włoskim, napotykam trudności w wyrażeniu moich myśli i intencji to:

nie podejmuję tematu

1.

porzucam / zmieniam rozpoczęty temat

$1 . \quad ; 2$. $; 3 . \quad ; 4 . \quad ; 5$.

przechodzę na język, który lepiej znam

1.___; 2.__; 3.___; 4 .___; 5 .

używam mimiki, gestu, mowy ciała

1.

staram się wypowiedzieć tak, jak umiem

1.

II. Jeżeli napotykam trudności w wypowiedzi, to staram się używać:

synonimy, lub przeciwne znaczenia słowa, którego nie znam

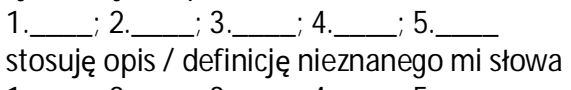

1.

podaję przykład uogólniający (np. krzesło ->mebel)

$1 . ; 2 . ; 3 . ; 4 . ; 5$

podaję przykład o węższym znaczeniu (np. mebel ->np. krzesło)

$1 . \quad ; 2 . \quad ; 3 . ; 4$.

wymieniam przykłady obrazujące (np. narodowości ->Polacy, Włosi, Czesi)

1.

tłumaczę dosłownie z języka rodzimego

$1 . \quad$;2. ;3. ; $4 . \quad ; 5$

tworzę nowe słowo w oparciu o znajomość reguł gramatycznych

1.

używam słowa „,wypełniacza” (np. „una cosa”, „taka rzecz”)

1.___-_ 2 .____-_; 3.__-_; 4 .__-_; 5 .

III. Jeżeli nie rozumiem mojego rozmówcy lub nie jestem pewny/a, czy dobrze zrozumiałem/am sens wypowiedzi i intencję rozmówcy, to:

proszę o powtórzenie

$1 . \quad ; 2 . \quad ; 3 . \quad ; 4 . \quad 5$

proszę o powtórne wyjaśnienie prostszymi słowami

$1 . \quad ; 2 . \quad \ldots ; 3$.

parafrazuję część wypowiedzi, żeby upewnić się, że dobrze zrozumiałem

$1 . \quad$;2. ;3. $; 4 . \quad ; 5$.

kieruję rozmowę na inne tory

$1 . \quad$;2. ;3. $; 4$. 